Naturalists' Notes, at the end of last century, while the Natural History Journal was published at York from 1877 until 1898. A contemporary, the Naturalist, but with no connexion with the present journal of that name, appeared monthly in York in 1834, mainly for school nature students.

\section{Conference of Educational Associations}

THE twenty-second annual Conference of Educational Associations was held at University College, London, on January 1-8. Dr. George Dyson, of Winchester College, in his presidential address on "Education for Life", said that though there is a great and growing interest in music and the arts, it is still true that the writing of poems, the making of pictures, the modelling of statues, the playing of sonatas, the composition of songs, are regarded as frills. Our education is a system of mental education, training only a fraction of human faculty and character. He recommended a system of differentiated secondary schools, one type being frankly a workshop.

The Great Hall was crowded on January 4 for a discussion on "The Failure of Modern Science to develop an Adequate Cultural Background to Life". Dr. W. W. Vaughan presided and the discussion was opened by Prof. Julian Huxley, who said that the defects of scientific education are over-specialisation, the failure to link science to other studies and over-emphasis on physics and chemistry, as against biology and related subjects. There is a tendency to devote too much time to practical work. He considers that science should be studied as an integral part of history and that more attention should be given to applied science, the aims of science teaching being a coherent general outlook in which scientific ideas are integrated, and the inculcation of the scientific method in human affairs. Sir Arnold Wilson's contribution to the discussion showed that he favours the teaching of science in elementary schools, in which he thinks there should be great development, and he stressed the ethical aspect of science teaching and its hope of bringing inspiration, strength and inward peace to mankind and stability to civilisation. The subsequent discussion elicited several useful suggestions, one being that young and rapidly developing branches of science might be considered from the viewpoint of their educational value. Several speakers referred to the importance of personal influences, the use of leisure, and emotional life and experience as contributing to 'cultural background'.

\section{Association of British Zoologists}

THE annual meeting of the Association of British Zoologists was held in the rooms of the Zoological Society in Regent's Park on January 6. On previous occasions the Association has been interested in the provision of revision classes in biology at the universities for school teachers. Dr. F. A. Dixey reported the work which the Council of the Association has done in the past year on this subject. Classes are now provided at several universities and have been well attended. In view of the expansion in the teaching of biology in schools which is now taking place, the subject is recognised as important, and the Council was asked to continue its activities. Mrs. M. D. Brindley, opened a discussion on the possibility of providing some means by which information concerning the British fauna could be made more easily and rapidly accessible. The preservation of the fauna among the rapid and widespread changes which are bound to occur in a thickly populated country is difficult, but it is a task in which zoologists must always be interested. Changes in the fauna are often of importance to the community. At present a very large amount of information on the natural history of the fauna has been collected but much of it is seattered through many, often obscure, journals.

Prof. D. M. S. Watson gave his views of the scope of the teaching which should be carried on in a university department of zoology. In order that the student may be able to deal later with the biological problems which will be the subject of his investigations, his teaching should be broad and should be concerned as much with the natural history and physiology of animals as with their structure. Prof. Watson gave an account of the way in which these views have been expressed in the design of the buildings which have recently been built for his department at University College. Some problems of zoological technique were also discussed. Prof. H. G. Cannon gave a lecture on the technique of making drawings for the illustration of zoological papers. It is hoped that the Council will be able to publish his lecture.

\section{Ninth International Congress of Pure and Applied Chemistry}

SPAIN will act as host for the ninth International Congress of Pure and Applied Chemistry, which will be held in Madrid on April 5-11, 1934, under the patronage of H.E. the President of the Spanish Republic and of the Spanish Government. The object of the Congress, which was to have been held in 1932, is to promote the progress of pure and applied chemistry, and to strengthen relations between chemists throughout the world. The president of the bureau of the Congress is Prof. Obdulio Fernández, and the general secretary is Prof. Enrique Moles; the address of the organising committee's office is San Bernardo 49 (P.O. Box 8043), Madrid (8). Membership is of three categories : honorary members, comprising the committees of honour and of patronage, and the official delegates of the Spanish Government and of the governments of other countries; supporting members, who pay the minimum amount of 300 pesetas; and active members, who pay a fee of 75 pesetas (about $£ 117 s .6 d$.). Members' ladies pay 25 pesetas only, but they will not be entitled, as members are, to receive publications in extenso, the daily bulletin, summaries of communications, or the report of proceedings. Membership is open to societies, institutions, etc., connected with any branch of pure or applied chemistry, and to individuals interested therein. Applications for membership should be made to the general secretary before February 15, 1934, and should be accompanied by a remittance 